\title{
Has the Fed Gotten Tougher on Inflation?
}

The federal funds rate has risen from about 3 percent in February 1994 to 6 percent today. Statements of Federal Reserve officials suggest that these actions can be interpreted as a "preemptive strike" against inflation-that is, policy was tightened in response to current indications that suggest higher inflation in the future. Many observers seem to have concluded that the Fed reacted more strongly to a threat of inflation than in the past. In this Letter, we attempt to shed light on this issue by comparing the Fed's behavior since early 1994 to its behavior at different points in the past. We find that policy in 1994 was similar to policy since the early 1980 s, and maintained a focus on keeping inflation low while remaining responsive to the business cycle.

\section{Benchmarks}

Developments since the mid-1960s provide convenient benchmarks to gauge the recent tightening of monetary policy. From 1965 to 1979 , consumer price inflation rose from less than 2 percent to above 12 percent. While developments such as the oil price shocks of the 1970 s were responsible for some of this increase, analysts generally agree that a quicker and more forceful response by the Fed would have kept inflation from picking up as much as it did over this period.

The years from 1979 to 1993 provide a sharp contrast. The Fed raised rates sharply from late 1979 to mid-1981 in an effort to bring inflation under control. Tighter policy was accompanied by two back-to-back recessions in the early 1980s; however, they were followed by the longest expansion in the post-war period. The Fed's concern about inflation was evident once again in the late 1980 s and early 1990s, when it raised the funds rate as inflation began to rise above 5 percent.

Below, we will use two different measures to summarize Fed policy in each of these periods and then use these measures to gauge policy in
1994. Our use of alternative measures reflects the inherent difficulty in finding ways to characterize policy. Any method will be subject to ambiguity and controversy.

\section{A reaction function}

Our first measure involves the use of a reaction function. Reaction functions attempt to describe the behavior of the Fed in conducting monetary policy. They measure the relationship between the Fed's policy instrument (such as bank reserves or the federal funds rate) and key variables that the Fed typically responds to in adjusting the stance of policy (such as inflation, real GDP and the unemployment rate). Thus, for example, a reaction function can suggest how the Fed would respond if the inflation rate were to rise by 1 percent. Reaction functions can change over time, depending in part on the weight the Fed places on various objectives of policy. For example, if the Fed becomes more determined to control inflation, then it will react more strongly to an increase in inflation.

A large number of reaction functions have been estimated by economists. We use one by Mehra (1994). In this function, the real (or inflationadjusted) funds rate tends to move toward its observed long-run average level of just under 2 percent. However, the Fed moves the nominal rate in response to a variety of factors. Consistent with our discussion above, Mehra finds that these factors differ in the periods before and after 1979. From 1979.Q4 to 1992.Q4, the Fed reacted to business cycle developments by "leaning against the wind." In other words, the funds rate tended to go up when real GDP was above the level of activity that could be sustained in the long run (the estimated level of trend GDP), and went down when real GDP was below this level. In addition, the funds rate also rose in response to an acceleration in inflation, and to a rise in the long-term bond rate, which Mehra interprets as an increase in expected inflation. 


\section{FRBSF}

The Fed's response over the 1965.Q4-1979.Q3 period was markedly different. Over this period the funds rate did not appear to respond significantly either to changes in the inflation rate or the long-term bond rate. And while the Fed also had a policy of leaning against the wind over this period, its response to cyclical developments was smaller than its response after 1979.

To determine whether the Fed changed its reactions in setting policy in 1994, we use Mehra's reaction function to see what the funds rate would have been if the Fed had continued to act as it typically did during 1979-1992. These estimates are compared to the actual funds rate in Figure 1. Assuming behavior that was typical in 1979-1992, the funds rate would have reached about 4 percent in the fourth quarter of 1994, roughly 1 percent below the rate that actually prevailed over that period. Thus, the Fed seems to have reacted more strongly than its earlier behavior would suggest. However, the difference is not statistically significant, which is to say that errors of this magnitude are not uncommon when trying to explain interest rates during the period over which the equation is estimated. At best, these results provide weak evidence that the Fed was more aggressive in heading off a surge in inflation than it has been in the past. A more tenable conclusion is that the Fed's reactions in 1994 were within a normal range of its typical behavior in the post-1979 period.

\section{Figure 1}

Federal Funds Rate: Actual vs. "Typical" Post-1979 Fed Behavior

\section{Percent}

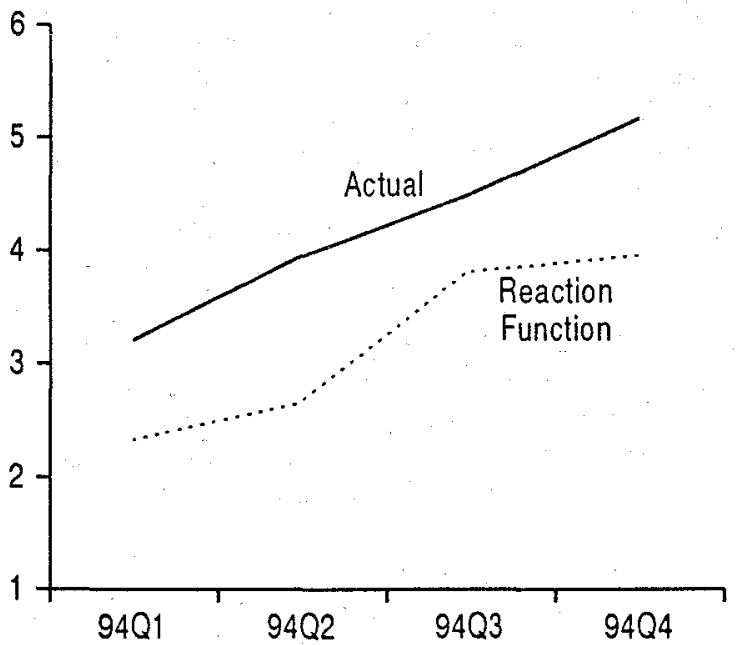

\section{A policy rule}

For our second measure we use a policy rule proposed by Taylor (1993). While Mehra's reaction function describes Fed behavior, Taylor's rule prescribes it. The rule is designed to ensure that monetary policy would achieve an inflation target of 2 percent in the long run (measured in terms of the GDP deflator), while still being responsive to the business cycle. Under the rule, the real funds rate would rise relative to its long-run average of 2 percent whenever inflation rises relative to its 2 percent target and real GDP rises relative to an estimate of its long-run trend level. (The similarity with Mehra's reaction function is not coincidental, since his work draws upon Taylor's rule.) Like any simple rule, there is room for disagreement about the underlying assumptions, such as the appropriate long-run (or equilibrium) real funds rate, or the trend level of real GDP. (For Figure 2, we estimated the trend using the method of Braun (1990), in which trend growth declines from about $3 \frac{1}{2}$ percent to about $2 \frac{1}{2}$ percent in several steps over 1965-1994.)

What makes this rule interesting from our perspective is that it provides a remarkably accurate description of the funds rate since the mid-1980s. Taylor had already shown that his rule closely fit the actual path of the funds rate from 1987 (when Alan Greenspan became Fed Chairman) to 1992 (when Taylor did his study). Figure 2 shows that the same close relationship continued to hold

\section{Figure 2 \\ Federal Funds Rate: Actual vs. Rule's Prescription for Fed Behavior}

\section{Percent}

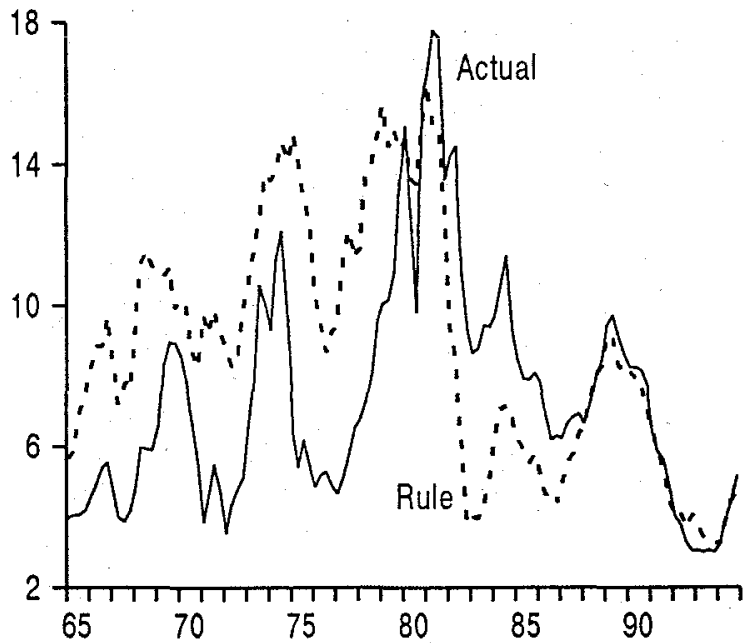


over 1993 and 1994 as well. Given that the rule incorporates an inflation rate of 2 percent, this result suggests that policy in 1994 was consistent with maintaining low inflation.

The figure also extends the rate suggested by the rule back to 1965 and plots it together with the actual funds rate. (Note that the line in the figure labeled "rule" uses actual values for inflation and real GDP, and does not incorporate the effects of following the rule on those variables.) A comparison of the two lines in the figure shows how the policy regime has changed over time. In making this comparison, it is useful to keep in mind that our use of the rule is somewhat different from what Taylor had intended. We are not taking a stand on whether the funds rate should have followed the rule during this period. Instead, we use the rule as a tool for comparing actual policy across different regimes.

Figure 2 shows that the actual funds rate was considerably lower than what the rule would have prescribed from the mid-1960s to the late 1970 s. Since this was a period of rising inflation, the results simply confirm that the rule would have done what it was designed to do-produce lower inflation than resulted from actual policy during this high inflation period. The figure also shows what the rule would have suggested during the Volcker era (1979-1987), when the Fed significantly reduced inflation from double digit rates to around 4 percent. In contrast to the pre1980 period, the funds rate over this period was consistently higher than what the rule recommends, suggesting that the Fed was more aggressive in reducing inflation than the rule would have been.

Taylor's rule, then, also confirms the shift in policy that occurred during the late 1970s, and demonstrates that since the end of 1979 the funds rate has been more responsive to changes in output and inflation than it was earlier. It also suggests that the behavior of the funds rate in 1994 was lititle different from its behavior over the preceding six or seven years. To the extent that the behavior of the funds rate has changed, the break seems to lie around 1987.

Before concluding, it is worth discussing why the Taylor rule matches Fed policy so well in
1994. At first glance this match appears surprising: The rule does not contain direct measures of expected future inflation, while-according to statements by Fed officials - the funds rate increases since 1994 have been designed to head off future increases in inflation. The rule does; however, include an estimate of the GDP gap - that is, real GDP relative to its long-run trend. Measures of the productive capacity of the U.S. economy, whether represented by trend GDP, industrial capacity utilization or the "natural" rate of unemployment, appear to figure prominently in Fed forecasts of future inflation (Greenspan, 1995, pp. 2-3). Thus, in a sense the rule does include a forecast of future inflation.

\section{Conclusion}

In this Letter we have shown that Fed policy during 1994 was more concerned about inflation than it was prior to 1980 . However, it is harder to make the case that the Fed's behavior over 1994 was different from the disinflationary regime established in the 1980s. And even though the two measures we have employed in this Letter suggest some differences in the way policy was conducted from 1979 to 1994, the most reasonable conclusion appears to be that the focus of policy has not changed very much over this period. The Fed's policy reactions in 1994 appear to be generally consistent with the desire for low inflation that it has exhibited since late 1979.

\section{John P. Judd \\ Vice President and Director of Research}

\section{Bharat Trehan Research Officer}

\section{References}

Braun, Steven N. 1990. "Estimation of Current-Quarter Gross National Product by Pooling Preliminary Labor-Market Data." Journal of Business and Economic Statistics, (July) pp. 293-304.

Greenspan, Alan. 1995. Testimony before the Committee on Banking, Housing, and Urban Affairs, United States Senate (February 22).

Mehra, Y.P. 1994. "A Federal Funds Rate Equation." Mimeo. Federal Reserve Bank of Richmond (March).

Taylor, John B. 1993. "Discretion Versus Policy Rules in Practice." Carnegie-Rochester Conference Series on Public Policy 39, pp. 195-214.

Opinions expressed in this newsletter do not necessarily reflect the views of the management of the Federal Reserve Bank of San Francisco, or of the Board of Governors of the Federal Reserve System.

Editorial comments may be addressed to the editor or to the author. . . . Free copies of Federal Reserve publications can be obtained from the Public Information Department, Federal Reserve Bank of San Francisco, P.O. Box 7702, San Francisco 94120. Phone (415) 974-2246, Fax (415) 974-3341. 


\section{Research Department}

\section{Federal Reserve}

Bonk of

\section{San Francisco}

P.O. Box 7702

San Francisco, CA 94120

Index to Recent Issues of FRBSF Weekly Letter

DATE NUMBER TITLE

10/7 94-34 The Recent Behavior of Interest Rates

$10 / 14 \quad 94-35$

$10 / 21 \quad 94-36$

$10 / 28 \quad 94-37$

$11 / 4 \quad 94-38$

$11 / 11 \quad 94-39$

$11 / 18-94-40$

$11 / 25 \quad 94-41$

$12 / 9 \quad 94-42$

$12 / 23 \quad 94-43$

$12 / 30 \quad 94-44$

$1 / 6 \quad 95-01$

$1 / 13$ 95-02

$1 / 20 \quad 95-03$

$1 / 27 \quad 95-04$

$2 / 3 \quad 95-05$

$2 / 10 \quad 95-06$

2/17 95-07

2/24 95-08

$3 / 3$

$3 / 10$

$3 / 17$

$3 / 24$

Explaining Asia's Low Inflation

Effects of California Migration

The Credibility of Inflation Targets

Why Banking Isn't Declining

Western Update

95-09

95-10

95-11

95-12
Risk-Based Capital Requirements and Loan Growth

Growth and Government Policy: Lessons from Hong Kong and Singapore

Bank Business Lending Bounces Back

Crises in the Thrift Industry and the Cost of Mortgage Credit

International Trade and U.S. Labor Market Trends

$\mathrm{EU}+$ Austria + Finland + Sweden + ?

The Development of Stock Markets in China

Gradualism and Chinese Financial Reforms

A Look Back at Monetary Policy in 1994

Economy Boosts Western Banking in '94

What Are the Lags in Monetary Policy?

Central Bank Credibility and Disinflation in New Zealand
Reduced Deposit Insurance Risk

Rules vs. Discretion in New Zealand Monetary Policy

Mexico and the Peso

Regional Effects of the Peso Devaluation

1995 District Agricultural Outlook

\section{AUTHOR}

Trehan

Laderman

Kasa

Zimmerman

Moreno

Gabriel

Kasa

Zimmerman

Booth/Chua

Mattey

Spiegel

Trehan

Parry

Levonian

Furlong/Zimmerman

Rudebusch

Hutchison

Mattey/Dean

Levonian/Furlong

Spiegel

Moreno

Mattey

Dean

The FRBSF Weekly Letter appears on an abbreviated schedule in June, July, August, and December. 